\title{
FAMILY SUICIDE BOMBING: A PSYCHOLOGICAL ANALYSIS OF CONTEMPORARY TERRORISM
}

\author{
RINDHA WIDYANINGSIH * AND KUNTARTO \\ Faculty of Humanity, Jenderal Soedirman University
}

\section{Abstract}

Terrorist organizations are now transforming into small cells and spreading their ideology to various parts of the world. The acts of terrorism in the Surabaya bomb case provide a new paradigm of the involvement of family members or an inner circle in their actions. The involvement of family members is considerably related to some psychological aspects. This study aims to provide a psychological analysis of suicide bombing terrors involving family members. The data obtained were analyzed using the perspective of Moghaddam's theory, 'staircases to terrorism'. The result indicates that the suicide bomber who has brought their family members in the action has gone through these six stages of psychological aspects: (1) Search for meaning. Actors seeking self and social meaning and finding reasons from the radical ideology adopted; (2) Presenting the ideology. The idea arises to fight those who are considered to do injustice, and the desire to change the system of government and politics is legitimate; (3) Cultivation stage. The process of ideology processing justification for resistance to those who are considered to be doing injustices; (4) Control over members. The stages of correct or wrong assessment based on the fatwa of the leader; (5) Moral engagement. The stage of identity confirmation and the process of polarization of groups of friends and opponents; (6) Recruitment, which is the stage of active in-

\footnotetext{
* Corresponding author: Rindha Widyaningsih, Jl. Dr. Soeparno No.60, Karangwangkal, Purwokerto Utara, Banyumas, Indonesia 53122.

E-mail: rindha.widyaningsih@unsoed.ac.id.
} 


\section{RINDHA WIDYANINGSIH AND KUNTARTO}

volvement in acts of terrorism ranging from planning, targeting, techniques used, time and location of targets to implementing recruitment.

Organisasi teroris sekarang bertransformasi menjadi sel-sel kecil dan menyebarkan ideologi mereka ke berbagai belahan dunia. Tindakan terorisme dalam kasus bom Surabaya memberikan paradigma baru tentang keterlibatan anggota keluarga dalam dalam aksi mereka. Pelibatan anggota keluarga ini tentu sangat berkaitan dengan aspek-aspek psikologis. Penelitian ini bertujuan untuk memberikan analisis psikologis atas aksi teror bom bunuh diri yang melibatkan anggota keluarga. Data yang diperoleh dianalisis menggunakan teori Moghaddam, 'staircases to terrorism'. Hasil penelitian ini menunjukkan bahwa pelaku bom bunuh diri yang melibatkan anggota keluarganya, melalui enam tahapan proses psikologis: (1) Pencarian makna. Aktor mencari makna diri dan sosial kemudian menemukan alasan dari ideologi radikal yang diadopsi; (2) Presentasi ideologi. Gagasan muncul untuk melawan mereka yang dianggap melakukan ketidakadilan, dan keinginan untuk mengubah sistem pemerintahan dan politik adalah sah; (3) Tahap kultivasi. Proses justifikasi ideologis untuk melawan mereka yang dianggap melakukan ketidakadilan; (4) Kontrol atas anggota. Tahapan penilaian benar atau salab berdasarkan fatwa pemimpin; (5) Keterlibatan moral. Tahap konfirmasi identitas dan proses polarisasi kelompok teman dan lawan; (6) Rekrutmen, yang merupakan tahap keterlibatan aktif dalam aksi terorisme mulai dari perencanaan, penargetan, teknik yang digunakan, waktu dan lokasi target hingga pelaksanaan rekrutmen.

Keywords: psychology of terrorism; radicalism; staircases to terrorism; suicide bombing; terrorism.

\section{Introduction}

Around the world, the number of terrorism crimes has always experienced an increasing trend from year to year. In Indonesia there were 73 terrorism cases in 2015, increasing to 163 cases in 2016, and in the following year 172 cases in 2017 (Ha- 
mid 2017). This figure is predicted to continue to increase about the upcoming Presidential Election in 2019. This prediction is getting closer to reality with the emergence of various bombing cases and arrests of suspected terrorists in various regions, although most of them are still concentrated in Java. The emergence of the Surabaya bomb terror, of the Gresik bombing, of the Mako Brimob Riot Kelapa Dua, of the Riau Regional Police attack (Damanik 2018) and various suspected cases of terrorist arrests in various regions such as Yogyakarta, Bekasi, Bandung, Jombang, Mojokerto, Malang, Medan and Rokan Hilir (Nugroho 2018) proves that terrorism cases will always exist and potentially arise in any area.

The data above also shows that the potential threat of terrorism regarding human resources is still quite significant. Data from the National Counter Terrorism Agency which states that in 2015500 Indonesian citizens were in Syria. Some source from the National Police said that 200 Indonesia citizens have been joining radical terrorist groups in Syria, and 53 have been deported from Syria. Collaboration between former terrorism prisoners and deported Syrians increasingly emphasizes that Indonesia is a country that is very vulnerable to acts of terrorism. This data certainly changes in the following year but broadly shows that the number of former terrorist prisoners in the community is quite large. A large number of former terrorism prisoners indicates that terrorism has many records of events occurring in Indonesia, as well as being a threat to the emergence of other acts of terrorism because they are considered to have the potential to spread radical teachings that carry out acts of terrorism. Various incidents and acts of terror involving people involved in members of radical religious groups indicate that terrorism and militant religious groups pose a serious threat to Indonesia (Zakiyah 2016). 
The leader of the terror movement could have been absent and sentenced to death, but the radical ideology of violence still has been flourishing secretly. Methods, patterns, and attack strategies are increasingly innovative and turn into movements that are adaptive to change. So far, terrorist acts in the form of bomb attacks are actions planned by terrorist groups with executors of single perpetrators, but the Surabaya bombings in May 2018 showed a new pattern that was unprecedented, namely the perpetrators were one family who at the same time carried out bombings committed suicide in three churches in Surabaya. Suicide bombers are one family, consisting of Dita Oeprianto (father), wife, and three children. The first bomb attack occurred at the Santa Maria Church without blemish with the perpetrator of the eldest child. The second bomb attack took place at the Indonesian Christian Church with the perpetrators of the mother with two children who took action to detonate themselves in a church fifteen minutes after the first bomb attack. The last bomb attack was a car bomb driven by his father who detonated himself at the Pentecostal Church, forty-five minutes after the second bomb exploded.

Terrorism is the subject of much attention from various parties and is studied from various scientific perspectives. Thus it gives birth to definitions that are very diverse and highly dependent on the defining point of view. On the one hand, a group of people can be called terrorists. But on the other hand, they are called freedom, liberation fighters, militants, mujahidin, and others who try to gain independence by striving for the ideology they believe.

Based on history and various studies, terrorism was born long before the late $20^{\text {th }}$ century which placed terrorism as a radical religious movement. Observing spreads various acts of terrorism throughout the world. The terrorist has many variants 
of movements that depart from different trigger factors. Sikh extremism in India, Madrid bomb attack, Aum Shinrikyo in Japan, and WTC bombing by the Al-Qaeda network are among examples of terrorism by basing religion as a reason and motivation for terrorism, but we also recognize separatist acts such as the Khawarij, DI/TII, GAM and Al Jamaah Al Islamiyah which based its movement on ideological struggle. The variants of the terrorist movement that exist show that terrorism cannot be considered merely an action with a religious background.

Referring to the data released by the Pattern of Global Terrorism 2000, the most common type of international terrorism cases is nuanced by religious and ideological motives (Mustofa 2012). Terrorism with a religious background understood at this time is seen as being born with an exclusive religious understanding and puritan movement that wants to purify religious teachings. Based on data it shows that the terrorism that currently exists and recognizes as a close relationship with religion, both religion as a goal and a religion that is only politicized. Religion as a goal means that the terrorism movement is an effort to uphold a particular religion or as an effort to purify the religious teachings. Religion as a politicization means that religion is only a cover for gaining sympathy from the masses who want to support terrorism efforts to gain power by utilizing religious emotions to legitimize acts of terrorism.

In religious societies like in Indonesia, religion infiltrated various social activities, both economic, political, familial and even recreational. Religious values have played a role in the background of various movements that occur in society, although religious radicalism is inseparable from the religious legitimacy and supremacy of the political forces that lie behind it (Widyaningsih, Sumiyem, and Kuntarto 2017). Religious symbols are more accessible to play as a trigger for a mass movement $(\mathrm{Ra}-$ 
khmat 2016). The magnitude of the influence of religion in the daily lives of Indonesian people makes it one of the reasons why religion-based terrorism still finds a safe and comfortable place to grow and develop.

Terrorism actions are always transformed and adaptive to changing times. Terrorism always displays the most sophisticated actions by utilizing the latest science and technology to improve their movement. Terrorism change not only by carrying out bombings that have a destructive impact on public facilities but also by psychological terrorism which ultimately leads to acts of terrorism with violence. This article examines the case in Indonesia what is the psychological study of the case of family suicide bombing terrorism?

\section{Literature Review}

The September 11, 2001 tragedy was an event that opened the eyes of the world to the crimes, and human tragedies called terrorism. Since the incident, there has also been an awareness of the existence of a common enemy namely terrorism. The act of terrorism itself is not new, but the act of terrorism which is motivated by religion is a new item at the beginning of the $2^{\text {nd }}$ millennium. In Indonesia, the effect of religious motivation is very pronounced, especially with the Bali bombings. Radical groups become a real threat that must be faced by the government following the disclosure of Bali bombers who are members of a trans-national Islamic radical group (Sukma 2003). The target of terrorism in the form of a bomb attack at the beginning of the second millennium leads to symbols that represent "the west" and efforts to eradicate "immorality", such as cases of Christmas night bombings in various churches throughout Indonesia (Fealy 2007), bombings at embassies and foreign-owned hotels (Pusponegoro 2017), and shopping centers (Singh 2004). This action culminated in the Bali bombings which succeeded in 
blasting the Sari Club and Pady Club which killed 202 people and 100 more who were injured (Hafidz 2003, 396). At the beginning of the 2000s, acts of terrorism that took place with perpetrators who were members of trans-national terrorist groups with religious motivation.

In 2010, the issue of terrorism had not been able to move from Indonesia. In 2011 there were only three terrorists recorded as attacks in various regions, including in Jakarta, Cirebon and Solo and Poso. However, terrorism that occurred from 2010 to 2015 was different from acts of terrorism from 2000 to 2009. The targets of terrorism that occurred in 2010 to 2015 which were civil society and law enforcement officers and the Indonesian National Army. Different from terrorism from 2000 to 2009 which directed acts of terror to Western objects, a bombing of police in Solo and Poso and the shooting of police in Kebumen and Purworejo for example. Besides, a surprise occurred when a suicide bomb was detonated at a mosque in Cirebon during Friday prayers. Mosques as places of worship for Muslims are subject to bombing, which is a place of worship for most terrorists in Indonesia who are Muslim (Subhan 2016).

The trend of acts of terrorism began to experience a shift in the middle of the second decade. The success of the apparatus in arresting and punishing the head of the terrorist kingpin/leader of the terrorist movement does not necessarily make radical ideology and acts of terrorism disappear (Zakiyah 2016). Based on the records of the various acts of terrorism that exist, terrorist members of terror groups (radical or ultranationalist groups) or lone wolf no longer dominate. From the Surabaya bombing case, an entirely new action from terrorist show involves all family members as suicide bombers. However, from the various variants of terrorist acts, religious motivation is still the main reason for acts of terrorism carried out both by perpetrators in groups, as well as families and single perpetrators. 
To explain the stages or psychological processes experienced by someone from an ordinary person or not a terrorist to being a terrorist, the theory of staircases to terrorism will be used (Moghaddam 2005). Stairs to terrorism are metaphors used by Moghaddam to describe and explain the process of becoming terrorism.

\section{Modification of Terrorism}

Terrorism groups arise for various reasons and motivations. So far the terrorist movements can be divided into four periods which in each mass have different characteristics of terrorism. According to David C. Rapoport, there are for waves of terrorism (Golose 2010).

First is an anarchist wave that took place in the period from 1880 to 1920 . This anarchist wave began in Russia and continued to develop until some time later.

The primary strategy used by terrorists at this time is to attack leading officials. On January 24, 1878, Vera Zasulich wounded a Russian Police commander who molested a political prisoner, and Zasulich declared himself a "terrorist" rather than a "killer". In 1879, the terrorist movement Narodnaya Volya appeared in Russia. This group practices terrorism as a way to take people's attention. They believe that terrorism is the most effective way. One of the actions carried out by this group was the overthrow and murder of the Russian Tsar, Alexander II in 1881.

The patterns of anarchism are manifestations of the hatred of society towards rules established by the authorities and establishment in society so that the acts of terror carried out aim to destroy all the rules of the ruler and bring down the establishment.

Second is anti-colonialism (anti-colonial wave) that occurred in the period between 1920 and around 1960. Colonial prac- 
tices motivate the movement by the winning countries of the first world war. The international momentum of the Versailles Peace Agreement was the momentum that marked the end of first world war. The implementation of the agreement was that the victorious countries of the war controlled the territories of the countries that had lost the war.

The emergence of a terrorist movement that demanded independence is triggered. The terms popularized to explain movements at this time are "liberation fighters", "guerrillas" and various terms that are positively meaningful in order to avoid the negative stigma of terror groups pinned to groups that commit rebellions and want independence. The essence that these groups use terrorist methods and methods is inevitable even using favorable terms. The emergence of terror groups that want liberation is crucial in the formation of new countries, such as Ireland, Israel, Yemen, and Al-Jazair.

Terrorists shift the target to the security forces of an existing government and no longer make state officials the primary target. This terrorist group develops their network in urban areas. The main force that sustains this group is practicing guerrilla warfare as a form of joint resistance. They have classified weapons and attackers that are difficult to identify. Some groups that practice terrorism in this period are Irgun in Palestine and Ireland Republic Army (IRA).

Third is the new left wave that occurred during the period between 1960 and 1980. A war between America and Vietnam marked the third wave. The consideration of a revolutionary process of what is in the first wave is in this period terrorist organizations have been born, such as the German Red Army Faction and the Italian Red Brigades. However, there were also groups who later used the revolutionary process as an opportunity to carry out separatist movements, for example, the ETA liberation movement and the Armenian liberation movement. 
Fourth is a wave of religious motivations or religion waves that began around 1979 until now. The event that illustrates the motivation of the religion that infiltrated was the emergence of the Iranian revolution in 1979 with the defeat of the Soviet Union in the Afghanistan war in 1989. After cripple of Soviet Union wins 1991, separatist movements began to take refuge behind religion or belief.

Fifth, in its development terrorist groups have a spectrum of movements and motivations that are difficult to distinguish, whether purely motivated by religion and trust or only aimed at specific interests, such as politics.

Who is called terrorism itself becomes very relative depending on the point of view used. For the sovereignty of power, terrorists are labeling given to groups that challenge legitimate governments in power. For terror groups, the consideration of terrorism is a logical and fair opposition from the people towards government terrorism, capitalism, racism, and imperialism. Terrorists often fight back to obtain moral justification by comparing the violence they commit with the violence committed by their opponents. With this comparison, terrorists try to position their actions and objectives at the same level of morality as those of their opposing governments. In World War II, the German occupying army labeled all resistance groups as "terrorists". Likewise the invaders against colonial peoples. The terrorist, see themselves as patriots who are fighting for independence. The Israeli government now sees Palestinian fighters as terrorists, whereas Palestinians call themselves fighters who free themselves from the country's terrorist occupation, Israel. A similar comparison can also be seen in the invasion by the United States of America against the people of Iraq and the presence of United States troops in various Middle Eastern regions, Saudi Arabia, whose perceive as a threat and a factor of instability in the region presence. 
Generally, terrorists try to avoid grouping their struggle tactics as criminal acts. The terrorists are more pleased if the framework of "war" of their struggle against the enemy in order to achieve political goals than as a terrorist, because the term terrorism related to criminal acts, then its validity as an elite of struggle is diminished when compared to the use of the term "war" to describe terrorism. The interesting "labeling" of terrorism, in general, is won by those in power over the people and those who are strong over the weak. By labeling terrorism with this second group, any actions taken by the first party are considered legitimate and justified. This picture is seen in the relationship between the rulers of Israel and the Palestinian people today. Because of the labeling gave to Palestinians as extremists and terrorists, the onslaught of tanks and bombs on helpless people is considered legitimate. "International Community" created by the interest groups of the Western ruling regime (United States) in order to gain legitimacy and mobilize support for repressive US military and political action against countries that do not support the global political policy of the United States and allow the ruling regime in Israel to terrorize the Palestinian people and Arabs in general.

Apart from the different constraints, there are dimensions of terrorism which have been used as a basis for limiting terrorism (Mubarak 2012). First, the legality dimension is understanding terrorism as a group action taken against the authorities. Here, the consideration of terrorism is something illegal. These limitations have disadvantages, including not seeing whether the action is an "action" or "reaction" to a ruler or a group that previously committed terrorism. Second, the dimension of violence, which is always associated with terrorism. Third, the objective dimension is understanding terrorism is always associated with efforts to achieve goals, both in the form of ideology, violence, 
and others. However, there is also terrorism whose purpose can be unclear. Fourth, the military dimension of understanding terrorism is associated with operations through military means.

Today's $21^{\text {st }}$ century terrorism is the epitome of the action of radical ideologies which are almost always preceded by religious fundamentalism. Religion is considered very useful for generating primordial emotions that are used to strengthen networks and organizational arrangements, launch actions, and be effective in achieving goals. The use of religion and religious symbols is not unconscious, that religion, in this case, is only used as a cover, but the strategy is effective in attracting the masses to join or at least support these terrorist groups. In this case, the emergence of religious and primordial emotions is used as a binder that fosters group cohesiveness so that people will voluntarily take action without feeling forced and even foster a willingness to sacrifice or altruistic behavior.

Various acts of terrorism with a religious background or at least using religion as a cover for struggle almost occur throughout the world. Violence in the name of religion also occurred in several religions but the events of September 11, 2001, ushered Islam as a religion that was identical to radical groups that carried out various acts of terror. Examples of religiously motivated acts of terrorism include the rebellion of Sikh extremism in India who want to establish a Khalistan Sikh state. The target of this group is Indian police and military as well as Hindus. They provoked acts of violence against Hindus throughout India as a form of revenge against the oppression carried out by Hindus in the past. The next example is Aum Shinrikyo in Japan. The doctrines that form the basis of this teaching of faith have been combined from several teachings, between Tibetan Buddhism, Hinduism, and Yoga. Aum Shinrikyo's group carried out acts of terrorism by using sarin gas at the subway station as a form 
of protest against the government. The Irish Republican Army (IRA) in Northern Ireland is another example of a religiously motivated act of terrorism and aims to replace legitimate government power. This revolt was carried out by Catholic nationalist groups who protested the practice of discrimination carried out by Protestants.

\section{The Psychological Process of Becoming a Terrorist}

This study discusses the process of someone was becoming a terrorist. The frame of mind used here is adopting Moghaddam's theory of staircases to terrorism (Moghaddam 2005). Stairs to terrorism are metaphors used by Moghaddam to describe and explain the process of becoming terrorism. The steps to terrorism consist of six stages that a person goes through to later turn into a terrorist.

\section{Ground Floor: Search for Meaning}

Finding self and social meanings become the beginning or necessary capital becomes terrorism, although not all people who are looking for meaning will fall into terrorist activities. At this stage, there is disappointment and deprivation of personal conditions, especially the conditions of other groups that are better than the group themselves. This condition is often referred to as the identity crisis which gives rise to the perception of injustice towards the group itself which is carried out by other groups.

Collective complaints create a perception that the government is not legitimate and the government system must be changed. Such perceptions will become stronger when individuals join a group. With the development of technology and information, the process of joining individuals in ideological groups becomes easy, through space and time.

In this first stage, the narratives about the injustices carried out by the government are presented to give a perception that 
the government has committed injustice, is hostile to Muslims and the criminalization of scholars, and various negative narratives that lead to the assumption that the government is inappropriate and deserving of hostility. In the process of recruiting radical groups from students, for example, the first step used to attract sympathy for prospective members is by presenting various news about Palestinian oppression by Israel, violence against Rohingya's Muslim ethnicity, criminalization of Rizieq Shihab, and acts of injustice against Muslims by the government.

Based on the results of interviews conducted by a television station that presented witnesses from school friends Dita Oeprianto, information was obtained that Dita Oeprianto had been exposed to fundamental understanding since he was still in high school. Dita and her group regard the ruling government as the toghut. In the days when they were still in school the narrative used to strengthen the government of the toghut was by presenting tyrannical narratives of the massacre of Bosnian Muslim ethnicity by the Serbs which were widely reviewed by Islamic magazines. This issue is one example of an issue that is processed to show a picture of the injustices experienced by Muslims.

\section{First Floor: Presenting the Ideology}

Nowadays, there was a spirit of finding enemies and opposing parties (scapegoats) who were considered to have committed injustices against their groups. So, the question is how to fight these injustices?

In the perspective of the scapegoat theory, when a person experiences the atmosphere of a crisis that befell him or his group, the usual psychological mechanism is to look for other parties as the cause of various crises that occur. This crisis happens because someone cannot exercise self-control, and usually, there are others who are chosen to be the cause of various crises and disappointments felt. However, because he is unable to fight di- 
rectly to the perceived target as the responsible party, the psychological mechanism of displacement of aggression is carried out, namely by choosing other targets that have real or symbolic ties to the primary target.

The figures that are in the spotlight in the world of terrorism generally adhere to a view that the world is not fair especially towards its groups. This view reflects that terrorists adhere to a belief called BIUW or Belief in Unjust World. This psychological aspect of belief is so imprinted that it controls almost all behaviors in the daily lives of terrorists. They see every phenomenon and unfortunate event that befell Muslims as a form of world injustice that is intentionally created and aimed at its identity group. They tend to represent themselves as defenders of their oppressed people so that their entire soul and body are fully intended to defend the people.

The strong narrative of tyranny experienced by Muslims, wherever they are, presents the desire to make changes. The road to change is believed to be by changing the system of government and politics that apply to the state. Dita Oeprianto who considered the democratic system adopted by Indonesia was wrong and needed to be changed, for example by presenting the concept of khilafah.

Second Floor: Cultivation Stage

At this stage, there is an ideological processing process to fight against those who have done injustices to their groups. The basic form is aggression displacement. Activities that often arise are in the form of condemnation and condemnation of parties who have been considered to be the cause of the injustice.

Ideology is often a source of justification to fight injustice and discrimination that occurs in a person. The consequences of such injustice are finding the cause of injustice and discrimination, or finding out the actor that causes various inconveniences 
experienced by a person or community. At that time there will be a demarcation limit between who is worthy of being called a friend and who is worthy of being called an opponent. It generally occurs not long after a person experiences periods of self-seeking meaning crises (Moghaddam 2005).

This stage was also marked by the emergence of an urge to fight oppression and tyranny that occurred before the eyes. At this stage, someone's emotions will be provoked to engage in various conditions, and then move them to act.

When emotions are moved, then someone who has entered this stage will seek justification from various sources to justify the actions and ideologies adopted. In the case of terrorists on behalf of religion, the justification of jihad as a tool to fight against tyranny and oppression gained energy from various inspirations of prominent religious thinkers or charismatic prominent ulama figures.

What is interesting to examine, presenting ideology in the struggle is not solely based on emotion and identity crisis, but in certain terrorist cases, it is also based on arguments that seem very intelligent and intellectual.

Ideology is an essential force for a terrorist, even though ideology is not the first driving factor that draws someone into the world of terror. Indeed, many studies such as Crenshaw (2001) state that ideology is not the first element that attracts someone to be part of a terror network, but ideology becomes the fuel that ignites the courage of someone to commit terror and destruction that was never imagined before (Gazi and Lutfi 2011).

For the context of terrorism that uses Islam as a dress and source of inspiration for the movement, it can be said that Salafism, a sect carried by conservative Islamic figures who want to restore patterns and lifestyles at the time of the Prophet. However, of course, it must be said that Salafism is diverse and experiences tremendous change and contextualization. Salafism, 
which is the ideological source of hardline Islam, is Salafism, which emphasizes the teachings of jihad as a form of resistance and a way to achieve the glory of Islam.

The Salafi movement (often called the Wahhabis) is a religious movement that contains many figures and factions, ranging from Osama bin Laden to the muftis in Saudi Arabia and reflects many positions related to political issues and violence. There is a source of unity that connects the hardline extremist Salafists and non-violent puritans. Although they adhere to the same teachings, they are different in seeing contemporary problems and how Salafi teachings are applied. Differences in the interpretation of context or situation create three factions in the Salafi movement, namely purists (purifiers), politicos (bearers of political Islam) and jihadists (bearers of jihad).

At this stage, they try to find the mastermind for the injustices that occur in Muslims. They blame the United States and the democratic system adopted by Indonesia. Therefore it is not surprising that many acts of terrorism are directed at destroying facilities that contain American elements or symbols, such as attacks on fast food restaurants. Terrorist groups also prohibit democratic systems because they are considered toghut (satanic government) that deserve to be destroyed. Based on this idea, they were hostile and attacked state security forces such as the Police. In many cases, attacks on target terrorist groups are police officers, police buildings or other state security symbols in addition to American symbols and security forces.

In the case of family suicide bombing in Surabaya, the perpetrators chose to detonate the church. Churches are targets for several reasons. The Muslim extremist teaches that Christians and the enemies of Islam and will seek to destroy it. There is a residual impact from two bitter communal conflicts that broke out between Christians and Muslims in Eastern Indonesia just after the country's authoritarian president, late Suharto, was 
forced to resign in 1998. Muslims attacked the deaths of Muslims at Christian hands in these conflicts, but extremists, then the bastions of what al-Qaeda called the "international Christian-Zionist alliance" that is aimed at destroying Islam - and thus a proxy for the West (Jones 2018).

\section{Third Floor: Control Over Member}

At this stage, the activities carried out in the form of seeing the world as black and white. It is only right or wrong, which true and false judgment is based on the fatwa of the leader. Leaders exercise control, control over members, in the form of planting ideas and moral beliefs that are true versus false. At this stage, all methods are condoned as long as they can be used to achieve the goal.

Leaders have a very large role in determining the direction and purpose of the group. The type of leadership of terror groups is usually based on charismatic leadership. There are respected figures and used as role models in determining group activities.

At this stage there began to be a desire to fight using various methods, including using violence to bombs. The resistance that is carried out in addition to being at the ideological level is through a series of physical actions that do not care about the impact of damage, because the most important thing is the goal is achieved.

\section{Fourth Floor: Moral Engagement}

At this stage, there is a process of polarisation of groups of friends and opponents. The so-called "them" are opponents who want to attack and destroy us. Social identity is formed steadily, namely the identity as a mujahid, and people/groups that are not in line are enemies.

Once the identity affirmation stage is reached, people will enter in the next stage, namely the emergence of a powerful sense of belonging to the group. This affirmation was triggered 
by what he saw, that the group was able to protect him from the outside world that was not fair to them. The consideration of the group is a place that provides security and saves from an identity crisis.

Conditions that are not following the expectations and pressures of life experienced often lead to disappointment and frustration. Humans have a self-defense mechanism that serves as a shield in facing the problems and pressures of life. One of the self-defense mechanisms that is considered adequate and easy to do is through religion. Religion is something doctrinal so that it can enter in the thickest part of human beings. Religion presents hope for a better life today even in a more enduring life after death. This reason is why religion is referred to as an "escape" for all the disappointments and frustrations experienced by humans.

Religion has two dimensions basically, namely the outer and inner elements in the form of religious, ethical beliefs and moral values. At the inner level, it will be difficult to experience a shift, because in the form of beliefs and beliefs that have been imprinted in the heart. Beliefs in merit, salvation, sin, error, and so forth are obtained through interpretation of texts with exclusive and absolute perspectives that are difficult to shift (Qodir 2014).

The role of religion as a drug of disappointment and frustration in humans raises religious involvement and develops into religious commitment. Higher frustration will increasingly encourage religious involvement. In Indonesian society that has high religiosity, religion is not only seen in the perspective of the profane and the sacred. Religion is a sacred dimension in totality, so it gets fast followers in a frustrated society, where they try to overcome frustration through deepening religion. This gap is cleverly seen by radical groups to get loyalists who are willing to take action various narratives that are built by wrapping 
all problems with the sacredness of religion. This reason shows why radical groups always get people who are willing to die for groups. They willing to be martyrs of marginalized groups who are willing to become suicide bombers, and attackers show for the sake of a belief that is believed to be a commitment in religion considered to be able to deliver them out of frustrating situations.

In radical groups, committing violence is part of a heroic struggle (jihad). This presumption arises as a result of the doctrine carried out on group members. The strength of the doctrine also led to the emergence of loyalty to the group so that they were willing to sacrifice themselves voluntarily for the sake of group ideology. For perpetrators of radical acts with violence (terrorism) death is a goal. Radical groups with violence do not know the word losing in their dictionary of struggle, only known as the win and win. Both win in the world and win in the hereafter. The victory of the world is obtained when they are able to carry out their actions successfully, namely eradicating their enemies consisting of the government that is toghut, the infidels (people of different religions), and the fāsiq (people who are religious but different streams). They are considered as martyrdom which is a guarantee of entering heaven to reach afterlife victory.

On the fourth ladder, they have arrived at the stage of preparing an attack ( $i^{\prime} d \bar{a} d$ ) before committing 'amaliyyāt jihad. The Dita Oeprianto family has a way to prepare bombs which are carried by car, wearing bomb vests given to his wife and children. Previously they had set a target, conducted a location survey and determined the attack.

\section{Fifth Floor: Recruitment}

At this stage, someone begins to get involved in terrorist acts that astonish the world. Active involvement was starting from planning, targeting, determining techniques, target time and 
place/location, to the certain activities in implementing recruitment.

The process of recruiting radical groups is an organized, systematic and massive process. The recruitment process consists of the following stages:

First, tabligh, (submission of messages/advice in general), for example tabligh akbar, doctrines activities, ex-skull etc. This initial activity is a gateway for the entry of radical terrorists who teach violence on the pretext of religion. They strengthen by quoting verses and the basis of the Shari'a which seem to justify the existence of a path of violence to purify religion. The recruitment process is usually done first on the circumference of the closest person, can be friends, relatives, coworkers, and so on. In this stage, it is usually still general and the doctrine is taught subtly and slowly. It aims to not be striking public attention and easy to enter into all circles.

In the modern era with the advancement of science and technology, this Tabligh process is not always carried out directly but can be done online through videos or websites that infiltrate radical notions through religious lectures. Many studies show that the inclusion of radical understandings among young people is through religious extracurricular activities in schools. The results of research from UIN and other research institutions clearly show that religious learning through extracurricular activities is one of the effective ways to recruit at this early stage.

Second, ta'tim or teaching. At the next level, people who have high enthusiasm is choosing and consistency during the tabligh. These people will then be guided by a mentor who will provide more in-depth and specific teaching. Teaching about the understanding and radical doctrine of terrorists begins with the brainwashing process to equalize perceptions, visions, and missions. In this phase also inculcated hatred and use of violence against other people who are considered enemies. 
Third, tamrin or training. The document of this continuing idea in the next stage is providing provisions in the form of training. In this phase hatred and the use of violence are intensified. The doctrine that the path of violence is "jihad" that must be pursued and eliminating the life of the enemy is considered an achievement. Training can be physical, for example, war training, or non-physical in the form of skills, such as assembling bombs. At the time of terrorist training members are equipped with SERE capabilities (Survival, Escape, Resist, Extract). Training is usually carried out in remote and far-off places, even some terrorist group recruits get training abroad, such as Afghanistan.

Fourth, tambish or selection. This selection phase will be chosen by people who have strong ideologies and are ready to die for "jihad". Rigorous selection is made to ensure group security, not all people who are exposed and undergo training qualify at this stage. Selection is made to determine the extent to which someone is involved in the group. There is a clear division of roles within the group organizational structure so that the right selection will guarantee the success of the action. This final selection determines who is genuinely ready to be a permanent member and loyal to the group.

Fifth, bai'at, implementing bai'at as a condition to become a member. In order to be legally recognized as a member, the chosen people will be taken an oath of allegiance through pledges. People who have been paid have high militancy, and they have the next regeneration task through the recruitment process.

The growth and development of the notion of radicalism which is the main trigger of acts of terrorism is a combination of internal psychological factors and has the support of external environmental factors. The psychological analysis aims to provide an explanation derived from factors in a person that influence motivation to appear as behavior. The process of internalizing the notion of radicalism is a long journey to become 
a permanent belief in a person. Eradication of radical organizations does not necessarily eliminate the notion of radicalism inherent in a person

The process of the perpetrators began to internalize radical notions until taking action was a long journey that had begun since high school. In contrast to many previous terrorists who preferred to close themselves to family or inner circle, Dita Oprianto preferred to invite family members to be actively involved in acts of terrorism. In the case of family suicide bombing in Surabaya, the perpetrator managed to plant seeds of radicalism in his family environment as early as possible consistently. The recruitment process as the fifth floor of staircases to terrorism is carried out within the scope of the nuclear family. The bombing was carried out as the culmination of the success of the spread of the radical ideology based on family love.

\section{Conclusion}

The case of family suicide bombers gives us an understanding of the methods and patterns of unexpected and innovative terrorist attacks. This case is relatively new because so far the bombers were single. The bombing was seen as a way of "jihad", but they considered this to be a quiet road to death. They loved their families very much and did not want their families and children to take the path of death. However, in the case of church bombings in Surabaya, the opposite happened, parents gave a picture of heaven through the way of jihad to their children and invited to take action together in order to gather together again in eternal life in heaven.

Staircases to terrorism expose us to an understanding of the process of one's involvement in radical terrorist groups. The process of entering into understanding and ideology of violence is not something that happens suddenly, but also through stages. How far the involvement of someone in a radical terrorist group can also be seen to what extent the stages that have been passed. 


\section{Bibliography}

Crenshaw, M. 2001. "Why America? The Globalization of Civil War." Current History December.

Damanik, Margith Juita. 2018. "5 Kasus Teror Di Indonesia Selama Mei 2018.” IDN Times. https://www.idntimes. com/news/indonesia/margith-juita-damanik/5-kasus-teror-di-indonesia-selama-mei.

Fealy, Greg. 2007. “Militant Java-Based Islamic Movement.” In A Handbook Of Terrorism And Insurgency In Southeast Asia, edited by Andrew Tan, 2:63-57. Cheltenham, UKNorthamton USA: Edward Elgar. doi:10.1016/B978-0340-71920-6.50033-9.

Gazi, and Ikhwan Lutfi. 2011. "Dari Orang Biasa Menjadi Teroris.” Jakarta.

Golose, Petrus Reinhard. 2010. Deradikalisasi Terorisme Humanis, Soul Approach Dan Menyentuh Akar Rumput. Jakarta: YPKIK.

Hafidz, Tatik. 2003. “Assesing Indonesia's Vulnerability in The Wake of The American-Led Attack on Iraq." In After Bali The Threat of Terrorism in Souteast Asia, edited by Ramakrishna Kumar and Tan See Seng. Singapore: World Scientific and Institute of Defense and Strategic Studies. doi:https://doi.org/10.1142/5438.

Hamid, Sadika Nuraini. 2017. "Kaleidoskop 2017: Kasus Terorisme Di Indonesia Selama Setahun.” Tempo, December.

Jones, Sidney. 2018. "Family Suicide Attacks: Indonesia Must Deradicalize Mothers And Kids Too.” NPR. https://www. npr.org/sections/parallels/2018/05/24/613383263/family-suicide-attacks-indonesia-must-deradicalize-mothers-and-kids-too.

Moghaddam, Fathali M. 2005. "The Staircase to Terrorism a Psychological Exploration.” American Psychologist 60 (2): 
161-69. doi:10.1037/0003-066X.60.2.161.

Mubarak, Zulfi. 2012. "Fenomena Terorisme Di Indonesia: Kajian Aspek Teologi, Ideologi Dan Gerakan.” Jurnal Studi Masyarakat Islam 15 (2): 240-54.

Mustofa, Imam. 2012. “Terorisme: Antara Aksi Dan Reaksi." Religia 15 (1): 65-87.

Nugroho, Fachri Sakti. 2018. "33 Terduga Teroris Di Seluruh Wilayah Indonesia Telah Diamankan Oleh Densus 88 Selama Sepekan." Tribun News. http:// wow.tribunnews.com/2018/05/16/33-terduga-teroris-di-seluruh-wilayah-indonesia-telah-diamankan-oleh-densus-88-selama-sepekan.

Pusponegoro, Aryono D. 2017. “Terrorism in Indonesia." Prehospital And Disaster Medicine 18 (2): 100-105.

Qodir, Zuly. 2014. Radikalisme Agama Di Indonesia. Yogyakarta: Pustaka Pelajar.

Rakhmat, Jalaluddin. 2016. Psikologi Agama. Jakarta: PT. Raja Grafindo Persada.

Singh, Bilveer. 2004. "The Challenge of Militant Islam and Terrorism in Indonesia." Australian Journal of International Affairs 58 (March 2004): 47-68. doi:10.1080/10357710 32000184764.

Subhan, Muhammad. 2016. "Pergeseran Orientasi Gerakan Terorisme Islam Di Indonesia (Studi Terorisme Tahun 20002015)." Journal of International Relations 2 (4): 59-67.

Sukma, Rizal. 2003. "Indonesia and The Challenge of Radical Islam After October 12." In After Bali in Threat of Terrorism in Southeast Asia, edited by Ramakrishna Kumar and Tan See Seng, 350-83. Singapore: World Scientigic and Institute of Defence and Strategic Studies. doi:10.1142/9789812561749_0016. 
Widyaningsih, Rindha, Sumiyem, and Kuntarto. 2017. "The Potential of Religious Radicalism Movement in Banyumas." Walisongo 25 (1): 203-30. doi:10.21580/ws.25.1.1807.

Zakiyah. 2016. "The Chronicle Of Terrorism And Islamic Militancy In Indonesia." Analisa 1 (1): 19-40. 